\title{
Low Temperature Refrigeration as an Alternative Anti-Pest Treatment of Dates
}

\author{
Ahmed LALLOUCHE ${ }^{1,2}$, Valentina KOLODYAZNAYA ${ }^{3}$, Mohamed Said BOULKRANE ${ }^{4}$ \\ Denis BARANENKO ${ }^{5 *}$ \\ 1, 3-5 ITMO University, Lomonosova str. 9, Saint-Petersburg, 191002, Russia \\ ${ }^{2}$ National Company of Refrigeration, Houari Boumediene str. 33, Skikda, 21000, Algeria
}

\begin{abstract}
Large amounts of dates are produced and consumed around the world each year. Apomyelois ceratoniae causes main losses during storage and export of date fruit. Fumigation is the most widely used treatment to prevent postharvest losses. However, this treatment negatively affects the biological value of dates, environmental and economic parameters of production. Widespread fumigation agent methyl bromide is toxic to a human body and contributes to the destruction of the ozone layer. The aim of the current work was to find a new method based on the use of low temperature refrigeration to reduce the pest and insect infestation preserving the nutritive value of dates during cold storage at the same time. A. ceratoniae mortality under different temperatures and dates respiration rate, sugar, organic acids, pectic substances content and sensorial characteristics were studied. The results indicate that at $-18{ }^{\circ} \mathrm{C}$ the $A$. ceratonie larva dies within $2 \mathrm{~h}$, the eggs and larvae within $24 \mathrm{~h}$ respectively. Thus, it is clearly shown that there is no need in using chemicals or irradiation to prevent dates pests. Physicochemical and organoleptic proprieties of dates were satisfactory during $360 \mathrm{~d}$ at $-18{ }^{\circ} \mathrm{C}$ and during $180 \mathrm{~d}$ at $+4{ }^{\circ} \mathrm{C}$. The low temperature refrigeration and storage at $-18{ }^{\circ} \mathrm{C}$ is recommended for dates to prevent pests and quality losses. It is apparently advantageous for environment and climate if compared with other anti-pest treatment variants.
\end{abstract}

Keywords - Dates preservation; pests; cleaner production; postharvest; storage

\section{INTRODUCTION}

The basic principles of bioeconomy include sustainable use of bio-resources [1] The bioeconomy approach which focuses on valorization of local bio-resources and bio-resource technologies is one of the promising strategies for improving resource efficiency [2]. Most heavy industries are main energy consumers and emitters of greenhouse gases which are drivers of global climate change [3]. Yet agriculture is also related with large fuel consumption, local emissions into the atmosphere and great amount of bio-resources being produced [4]. Implementation of new and alternative methods of treatment and production can improve yields of agricultural resource and either decrease the environmental impact [5]. It is especially important because environmental factors can affect food quality and consumer safety [6].

In date-producing countries date palm fruit (Phoenix dactylifera L.) have been used for centuries to treat a variety of ailments in various traditional systems of medicine. The total world production of dates was 7.6 million metric tons (MMT) in 2014, which represents more than 2.2 times increase compared to 1990 production of 3.4 MMT [7]. Dates are considered nutritious and high-energy food (1180 kJ per $100 \mathrm{~g}$ ) because they are rich in sugars providing quick energy intake [8], minerals [9], vitamins [10], phenols, flavonoids, anthocyanins and carotenoids with

\footnotetext{
* Corresponding author.

E-mail address: denis.baranenko@niuitmo.ru
} 
functional properties [11]. Dates are known to be heart-healthy [12], and their soluble fiber helps against constipation [13]. Antioxidant properties of date fruit vary depending on the amount of phenolics, vitamins $\mathrm{C}$ and E, carotenoids, and flavonoids [14], [15].

According to their high nutritive value and nutrient content, dates are subjected to many diseases and pest attacks which result in quantitative and qualitative losses and changes in chemical composition, affecting the nutritive value of the product [16]. Insects cause major infestations (Coleopterans, Lepidopterans and Hymenopterans), as well as pathogenic bacteria (such as Escherichia coli, Staphylococcus aureus and Bacillus cereus), and several mold and yeast genera. In Algeria, one of the most economically important pest species is the carob moth (Lepidoptera: Pyralidae), Apomyelois ceratoniae (Zeller), which infests $20 \%$ of harvestable crop annually, causing great economic losses [17].

In many countries around the world, to fight and reduce the microbial, pest and insect infestations, various physico-chemical and biological methods are used [18]. At present, in producing countries the most utilized methods are the methyl bromide and phosphine base fumigation [19]. Reference [20] compared methyl bromide fumigation and irradiation of Zahdi dates reporting the both techniques were efficient for disinfestation during the first period of storage ( $25 \mathrm{~d})$. However, the reinfestation of dates occurred during storage, and live insects were detected. Thus, disinfested dates must be protected from reinfestation by storage at low temperatures and in insect proof packages. Methyl bromide is a colorless, odorless gas, and it is three times heavier than air. These specifications allow it to penetrate the mass of the product. Despite the good results of disinfection with methyl bromide, it has negative effects: it binds chemically with proteins of dates, and it is toxic to a human body. Furthermore, methyl bromide contributes to the destruction of the ozone layer [21]. As a consequence, the use of these fumigants is banned in many countries outside of most African and Asian dates producing territories.

In recent years, several different methods have been investigated as alternatives to methyl bromide fumigation. Traditional and new postharvest techniques developed for date fruit treatment include irradiation [22], microwave, ozonation [23], essential oils, vacuum and modified atmosphere packaging [24], heat treatment [25]. However, due to legal constraints, high cost and/or lack of efficacy, none of these methods has found a wide application in practice. Alternative means of fighting against pests are constantly being sought.

Currently, the dates are stored at temperatures of $0{ }^{\circ} \mathrm{C}-5^{\circ} \mathrm{C}$. A long period of storage under these temperatures retards the growth of date worms, but does not result in their death. It is also known that dates freezing temperature can be lower than $-18{ }^{\circ} \mathrm{C}$ [26] and the temperature of $-15^{\circ} \mathrm{C}$ is lethal for Apomyelois ceratoniae [27]. Thus, low temperature refrigeration can be used as an anti-pest treatment of dates.

Therefore, the aim of the current work was to find a new method based on the use of low temperature refrigeration to reduce the pest and insect infestation preserving the nutritive value of dates during cold storage at the same time.

\section{MATERIALS AND MethodS}

A. ceratoniae mortality under different temperatures and dates respiration rate, sugar, organic acids, pectic substances content and sensorial characteristics were studied. All experiments were performed with at least three replicates, data was processed by methods of mathematical statistics at theoretical frequency 0.95 . 
Dates fruits, Deglet Nour variety (Phoenix dactylifera L.) cultivated and harvested at fully mature stage in the Saharan oasis Tolga (Biskra province, Algeria). For studying A. ceratoniae mortality under different temperatures naturally-infested dates (Deglet Nour cv.) with the moth larvae and live larvae were collected. About $200 \mathrm{~g}$ of infested dates were placed in polystyrene boxes and kept under three different temperatures: $-5{ }^{\circ} \mathrm{C},-10{ }^{\circ} \mathrm{C}$ and $-18{ }^{\circ} \mathrm{C}$. Depending on the temperature, storage time intervals were different ranging from $1 \mathrm{~h}$ to $24 \mathrm{~h}$.

For studying effect of negative and positive temperatures on Deglet Nour quality collected dates were placed in $1 \mathrm{~kg}$ carton boxes and stored under two different temperatures, at $+4{ }^{\circ} \mathrm{C}$ and $-18{ }^{\circ} \mathrm{C}$, respectively.

To determine the effectiveness of low temperatures treatment on the larvae viability, dates were maintained at $+23{ }^{\circ} \mathrm{C}$ for $24 \mathrm{~h}$ after refrigeration. The viability of larvae and eggs was also evaluated after heating the dates in an oven at $37^{\circ} \mathrm{C}$ for $72 \mathrm{~h}$, exposing them to low temperatures for $360 \mathrm{~d}$ and storing at $+23{ }^{\circ} \mathrm{C}$ for $30 \mathrm{~d}$. Then the state of the larvae was analyzed by their external aspects (mobility and color). Live and dead insects (larvae) were manually counted.

Respiration rate was determined by the titrimetrically-corrected method based on the determination of the amount of released carbon dioxide.

Sugar and organic acids content was analyzed by the gas chromatography-mass spectrometry (GC-MS) on a chromatograph TQ-8040 (Shimadzu, Japan) using a capillary column HP-5MS (30.0 m; $0.25 \mathrm{~mm} ; 0.25 \mu \mathrm{m} 5 \%$ diphenyl $95 \%$ dimethylpolysiloxane phase) at a flow rate of inert gas (helium) $0.5 \mathrm{~mL} \mathrm{~min}^{-1}$. The initial heating temperature column was $130{ }^{\circ} \mathrm{C}$, final $-250{ }^{\circ} \mathrm{C}$, heating rate $-4{ }^{\circ} \mathrm{C} \min ^{-1}$. Detector temperature was $250{ }^{\circ} \mathrm{C}$, injector temperature was $300{ }^{\circ} \mathrm{C}$, the sample injection volume was $1.0 \mathrm{~mL}$. Test compounds were identified using the electronic library.

Pectic substance content was determinated with the method based on the reaction of galacturonic acid with carbazol. Three fractions were studied: 1 - water-soluble (salt of pectic acid - pectin); 2 - the intermediate solubility fraction (chloride acid, acetic acid, pectic acid); 3 - insoluble substances in water (protopectin).

The sensorial characteristics of dates were evaluated by trained panel of 12 members. Twelve panelists (aged 22-45 years) familiar with sensory evaluation techniques estimated the sensory properties of the dates samples.

\section{RESUlTS AND DisCUSSION}

\subsection{A. ceratoniae Mortality under Different Temperatures}

Table 1 shows the influence of temperature and exposure duration on dates moth larva viability. According to the results keeping dates under $-5^{\circ} \mathrm{C}$ for $24 \mathrm{~h}$ does not lead to larvae death, but only slows their movement and slightly change their color. It is obvious this temperature results in the larva being in a state of antibiosis with physiological and biochemical processes slowed as.

At $-10{ }^{\circ} \mathrm{C}$ the larvae die after four-hour exposure, changing its color from gray to dark brown after $5 \mathrm{~h}$. At $-18^{\circ} \mathrm{C}$ after two-hour exposure the larvae die and after $3 \mathrm{~h}$ their color varies from pale brown to dark brown.

At $-10{ }^{\circ} \mathrm{C}$ and $-18{ }^{\circ} \mathrm{C}$, the larvae death can be explained by the freezing of free water contained in their tissues, increasing the concentration of dissolved substances in water and, as a consequence, the breakdown of metabolic processes.

Our studies have established that the signs of live larvae and eggs disappear in dates after $24 \mathrm{~h}$ exposure at $-18^{\circ} \mathrm{C}$. 
It was demonstrated that dates resist to low temperature [28], and Table 1 shows that negative temperatures can significantly reduce their insect infestation. Cooling down to $-18{ }^{\circ} \mathrm{C}$ or lower for at least $48 \mathrm{~h}$ (from the time when the fruit temperature reaches $-18{ }^{\circ} \mathrm{C}$ or lower) is enough to kill insects at all life stages in stored products. Cooling to this temperature does not lead to dates freezing as they remain soft without ice forming inside. This corresponds to the initial freezing point lower than $-18{ }^{\circ} \mathrm{C}$ for dates having total solids content higher than $60 \%$ [26].

TABLE 1. Resistance of A. CERATONIAE LARVAE to NEGATIVE TEMPERATURES

\begin{tabular}{|c|c|c|c|c|}
\hline $\mathrm{t},{ }^{\circ} \mathrm{C}$ & Dates retention period, $\mathrm{h}$ & State of larvae & Larvae mobility & Larvae color \\
\hline \multirow{3}{*}{-5} & 12 & Alive & +++ & Pale pink \\
\hline & 18 & Alive & +++ & Pale pink \\
\hline & 24 & Alive & ++ & Pale pink \\
\hline \multirow{3}{*}{-10} & 3 & Alive & ++ & Pale pink \\
\hline & 4 & Dead & - & Grey \\
\hline & 5 & Dead & - & Dark brown \\
\hline \multirow{3}{*}{-18} & 1 & Alive & + & Pale pink \\
\hline & 2 & Dead & - & Pale brown \\
\hline & 3 & Dead & - & Dark brown \\
\hline
\end{tabular}

Note: normal mobility: +++; average: ++; slow: +; non:-.

Other treatments such as exposing dates to high temperatures of $65{ }^{\circ} \mathrm{C}-80{ }^{\circ} \mathrm{C}$ for 30 min to $4 \mathrm{~h}$ at high humidity are used to control A. ceratoniae [29]. However, this approach is not always very efficient for dates with high moisture content in terms of controlling insects. Heated air at $50{ }^{\circ} \mathrm{C}-55^{\circ} \mathrm{C}$ for $2-4 \mathrm{~h}$ (from the time the fruit temperature reaches $50{ }^{\circ} \mathrm{C}$ or higher) is effective for insect disinfestation [25], but the use of higher temperatures is not recommended as it makes the color of dates darker. Reference [30] reported that boiling water is more efficient in controlling insect infestation of dates than exposing to hot air at $70{ }^{\circ} \mathrm{C}$. However, hot water also increases sugar loss that can reach up to $20 \%$. The combination of convective and microwave heating is a good strategy for disinfestation date fruits [31], however it requires equipment with high energy consumption and capital costs.

Thus, if negative temperatures effect dates quality less or equal than other types of treatment, their usage seems to be promising and easy for pests control.

\subsection{Effect of Different Temperatures on Dates Respiration Rate}

One of objective indicators of date preservation effectiveness is respiration intensity, which is not only an important source of energy used for the implementation of various synthetic reactions, but also the source of many metabolites generated as intermediate products of respiration, namely the basic constituents for the synthesis "de novo" substances.

Dates typically have low respiration and ethylene production rates with very limited or no ethylene effect, particularly at Rutab and Tamar stages, because of low water content, therefore, offering limited use of active packaging. Due to low respiration rates, the quality of dates harvested change slowly as compared to other high respiring fruit. Respiration rates also reduce with moisture content decrease. 


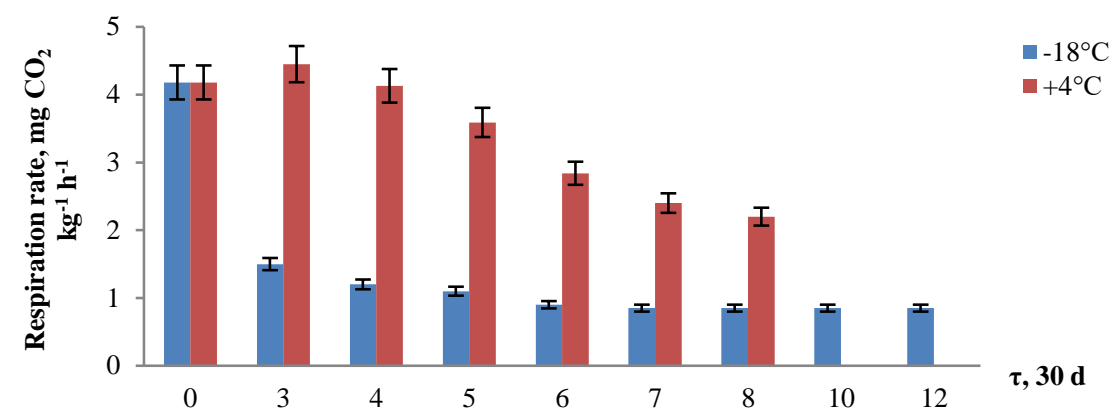

Fig. 1. Dates respiration rate during storage at $+4{ }^{\circ} \mathrm{C}$ and $-18{ }^{\circ} \mathrm{C}$. Error bars here and after show the relative errors.

According to Fig. 1, during the storage process of dates at $+4{ }^{\circ} \mathrm{C}$, the respiration rate decreased 2.1 times, reaching its minimum after $240 \mathrm{~d}$. At $-18{ }^{\circ} \mathrm{C}$, during $120 \mathrm{~d}$ of storage, respiration rate decreased 3.4 times, and then it remained constant.

Respiration of dates generally depends on the activity of dehydrogenases and oxidoreductases, with the most important being the terminal oxidases - phenoloxidase, peroxidase and catalase [32]. It was demonstrated that the respiration rates increase with higher moisture content and temperatures. Ethylene production rate of dates is also very low at $20^{\circ} \mathrm{C}$, i.e., $<0.5 \mathrm{~L} \mathrm{~kg}^{-1} \mathrm{~h}^{-1}$ for Khalal stage, and $<0.1 \mathrm{~L} \mathrm{~kg}^{-1} \mathrm{~h}^{-1}$ for Rutab and Tamar stage dates [29]. Reference [33] reported that dates at Rutab and Tamar stages, which are the most common harvest stages, have low respiration rates $\left(<5 \mathrm{~mL} \mathrm{CO}_{2} \mathrm{~kg}^{-1}\right.$ at $\left.20^{\circ} \mathrm{C}\right)$.

During the storage of dates, weight loss was studied, which averaged $0.5 \%$ per $30 \mathrm{~d}$ at $+4{ }^{\circ} \mathrm{C}$, and $0.01 \%$ per $30 \mathrm{~d}$ at $-18{ }^{\circ} \mathrm{C}$. The weight loss might be attributed to the respiration process and/or to the loss of moisture of Deglet Nour dates during cold storage.

\subsection{Dates Sugar Content}

Dates contain a high concentration of sugars, which are considered the main component. These carbohydrates are mainly reducing sugars in the form of glucose, fructose, mannose and maltose and non-reducing sugars (primarily sucrose), as well as small amounts of polysaccharides (such as cellulose and starch). Fruit sugars play a significant part in both preserving fruit quality and determining its nutritional status [34].

During cold storage of dates, in particular at positive temperatures, some carbohydrates undergo more significant changes including mono- and disaccharides as they are main substrates of respiration.

Fig. 2 and Fig. 3 illustrate the experimental data of mono- and disaccharides content variation in dates, depending on the time of storage at $+4{ }^{\circ} \mathrm{C}$ and $-18{ }^{\circ} \mathrm{C}$ 


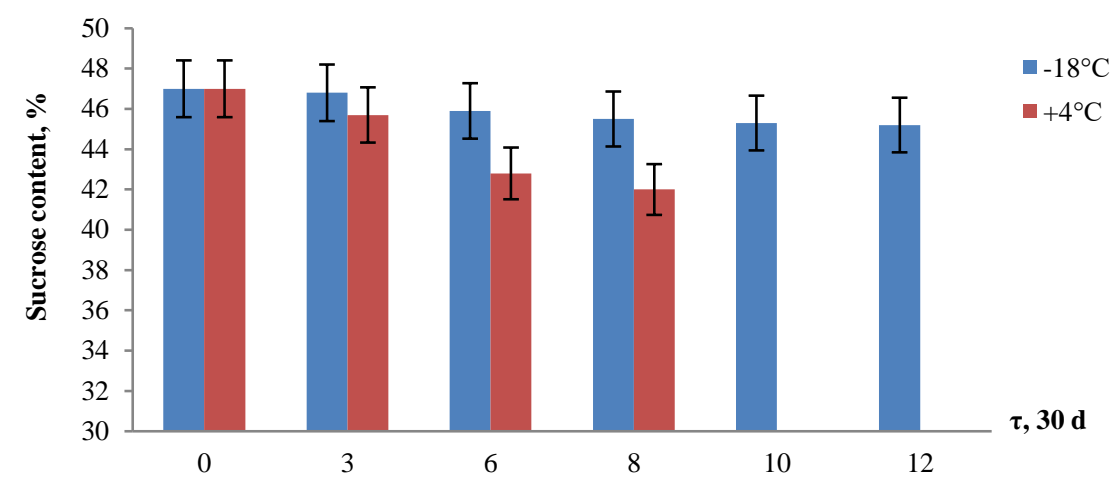

Fig. 2. Sucrose content of dates during storage at $+4{ }^{\circ} \mathrm{C}$ and $-18{ }^{\circ} \mathrm{C}$.

As seen in Fig. 2, during the storage period, the date sucrose content decreased at both positive and negative temperatures. This occurs due to the fact that sucrose is hydrolyzed to monosaccharides which are expended because of respiration and enzymatic activity in the fruit [35].

In Fig. 3, at $+4{ }^{\circ} \mathrm{C}$ the monosaccharides content decreased because they expended during respiration.

At $-18{ }^{\circ} \mathrm{C}$, their content decreased at a lower rate until the end of the frozen storage period, which is explained by the slowdown of the respiration rate (Fig. 1). It was demonstrated that the storage duration and conditions such as temperature and moisture affect the sugar content of dates [36]. However, many studies reported that reducing sugars (fructose and glucose) in date fruit increased while the sucrose sugar decreased at the end of the $360 \mathrm{~d}$ of frozen storage. Other studies reported a decrease in the reducing sugars of date fruit was at the end of six months frozen storage.

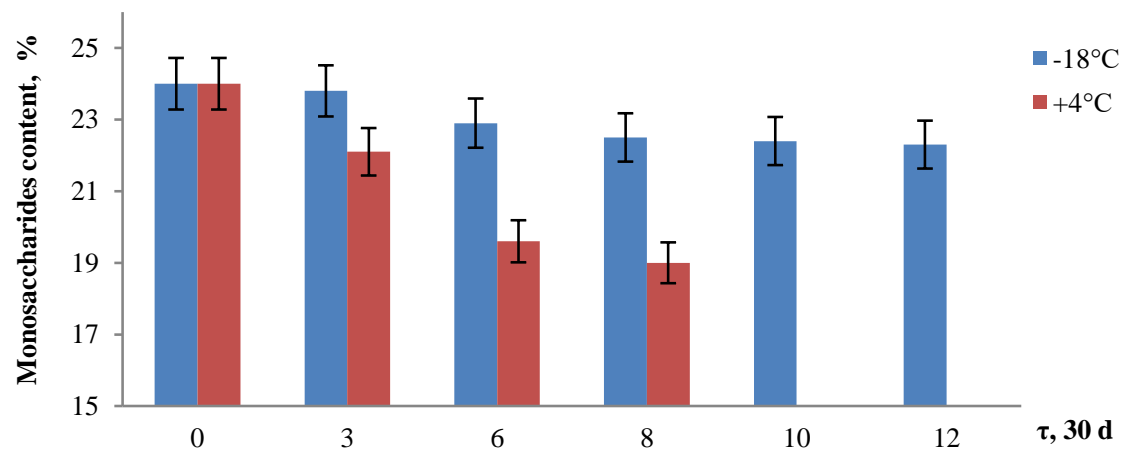

Fig. 3. Monosacharides content of dates during storage at $+4{ }^{\circ} \mathrm{C}$ and $-18{ }^{\circ} \mathrm{C}$.

Fig. 2 and Fig. 3 show that there were significant differences between the sucrose and monosacharides values of the fruits stored at $-18{ }^{\circ} \mathrm{C}$ and at $+4{ }^{\circ} \mathrm{C}$ for the different storage times. From the results mentioned above it is evident that the changes in sugars were much lower in case of fruit stored at $-18{ }^{\circ} \mathrm{C}$. This approach leads to the best preservation of date fruit quality. 


\subsection{Pectic Substances Content of Dates}

During the cold storage of fruit, the polysaccharides are subjected to significant changes, in particular, pectic substances that affect the structure of plant tissues.

In plant products, the hydrophilic tissue properties responsible for the product's resistance to the action of negative temperatures depend on the content of pectin substances and the proportion of pectin and protopectin.

Fig. 4 and Fig. 5 show the variation of the content of total pectic substances, protopectin, pectin and pectic acid in the dates storage process, at $+4{ }^{\circ} \mathrm{C}$ and $-18{ }^{\circ} \mathrm{C}$. According to our results, the hydrolysis reaction rate constants (pseudo first degree) of the protopectin and pectin are 0.324 and $0.043(30 \mathrm{~d})^{-1}$ respectively. Therefore, the rate of protopectin hydrolysis is 7.5 times higher than the pectin. Thus, based on the research we have established the ratio of the different fractions of pectin substances variation depending on the storage time of the dates Deglet Nour variety at $+4{ }^{\circ} \mathrm{C}$ and $-18{ }^{\circ} \mathrm{C}$. It was shown that protopectin in dates is hydrolyzed in the process of storage under both positive and negative temperatures, while pectin is hydrolysed only under positive temperatures [37].

As seen from Fig. 4 the total pectic substances content decreased, as consequence, the intermediate soluble fractions in water increased, and the protopectin insoluble fraction decreased. This occurs due to the fact that protopectin under the action of protopectinase is hydrolyzed with the formation of intermediates (pectin, pectic acid), as well as finished products (D-galacturonic acid, arabinose and xylose). As a result of these reactions, the pectin content increased. It should be noted that during the dates storage process at $+4{ }^{\circ} \mathrm{C}$ pectin was also hydrolyzed with the participation of pectinase and polygalacturonase enzymes. However, the rate of pectin hydrolysis was less than the protopectin, which content increased.

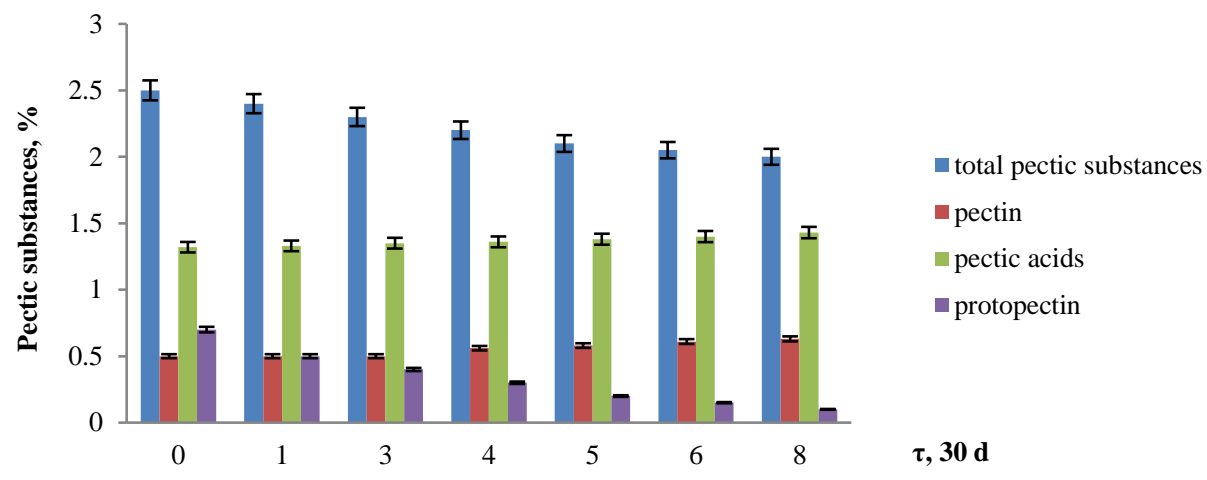

Fig. 4. Pectic substances content of dates during storage at $+4{ }^{\circ} \mathrm{C}$.

Fig. 5 shows that during the storage process of dates at $-18^{\circ} \mathrm{C}$, the total pectic substances and protopectin slightly decreased. The quantity of pectin did not change, but the fraction of intermediate solubility increased. As known the variety of Deglet-Nour dates is distinguished by a high content of mono-, di- and polysaccharides (more than $70 \%$ ), low water content (23\% to $25 \%$ ), and most of its bound water, it has a low cryoscopic temperature and does not freeze at $-18{ }^{\circ} \mathrm{C}$. During the negative temperature storage of dates, biochemical processes in plant tissues occur, but their speed is much lower than during the storage under the positive temperatures. Thus, the constant of hydrolysis rate of the protopectin is $0.044(30 \mathrm{~d})^{\mathbf{- 1}}$. 


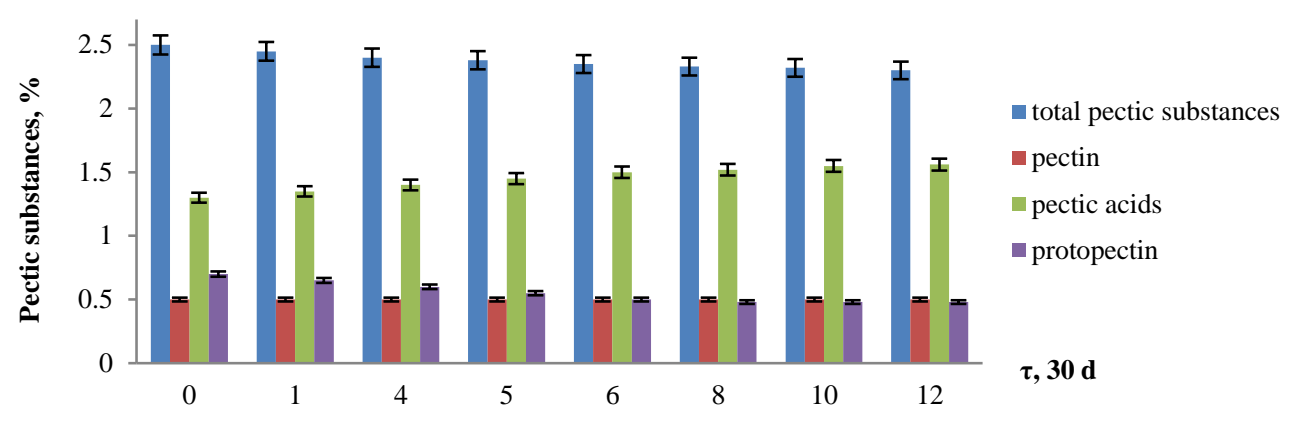

Fig. 5. Pectic substances content of dates during storage at $-18^{\circ} \mathrm{C}$.

\subsection{Dates Organic Acid Content}

During the storage of dates, many compounds participate in the biochemical exchange process such as carbohydrates and organic acids. The most important one is malic acids it has a specific fruity, mellow, smooth, tart and sour taste in fresh fruit [38]. Moreover, the presence and composition of organic acids may be affected by various factors such as a variety, growing conditions, maturity, season, geographic origin, fertilization, soil type, storage conditions, amount of sunlight received, and harvest time.

As shown in Fig. 6, at $+4{ }^{\circ} \mathrm{C}$ the total content of organic acids decreased, this implies they are implicated in the metabolism process, because they participate in the synthesis of many enzymatic and aromatic substances [39]. That is why, at the initial phases of storage the oxidation process dominates, and at the final ones the decarboxylation occurs. During the first months of storage under negative temperatures, there was an increase in the amount of acids because of their synthesis as a result of the partial oxidation of mono- and disaccharides. After that time, they slightly decreased.

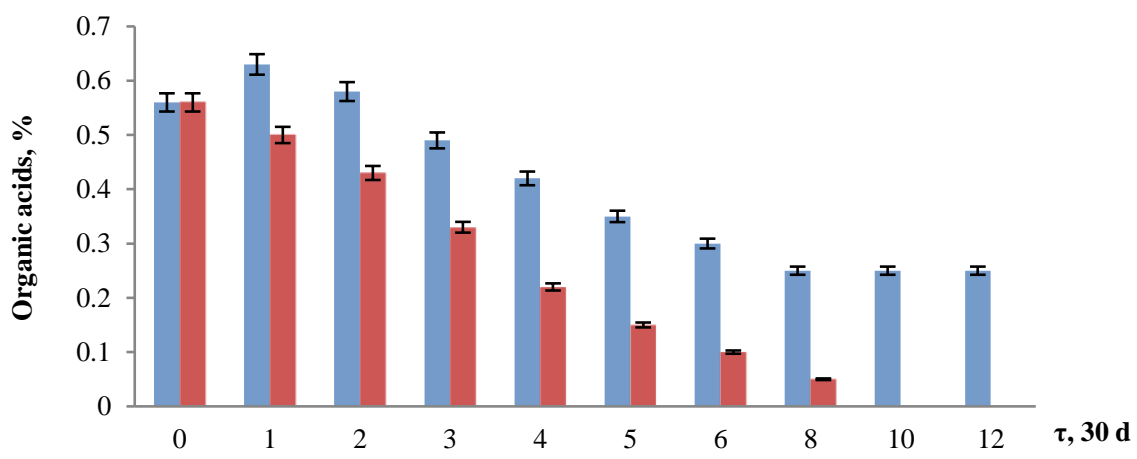

Fig. 6. Organic acids content of dates during storage at $+4{ }^{\circ} \mathrm{C}$ and $-18{ }^{\circ} \mathrm{C}$.

\subsection{Sensorial Analysis of Dates}

It is known that dates quality and maturity stage effects the fruit color [40]. It was found that during the storage at temperature $+4{ }^{\circ} \mathrm{C}$, there are significant changes occurred after $180 \mathrm{~d}$. Date fruit color changed from a light brown to a slight dark brown. Probably it happens due to the enzymatic oxidative browning of phenolic compounds and non-enzymatic browning reactions 
involving the Maillard reaction and tannins [41]. It was also reported that the main factors of darkening using higher temperatures for a long storage time [42], [43]. Darkening of dates can occur beyond their natural colors during the storage. Reference [29] reported that date fruit quality loss resulting from pathological and physiological deterioration rises with increasing moisture content and storage temperature. However, during the $360 \mathrm{~d}$ of storage at $-18{ }^{\circ} \mathrm{C}$ organoleptic and color indicators remain unchanged. Hence, at low negative temperatures the enzymes activity slowed. However, the controlled atmosphere storage of fruit reduces browning [44]. In our study, low negative temperatures preserved the color and organoleptic characteristics better than positive ones.

\section{CONCLUSION}

For the final decision on the use of the low temperature dates preservation the assessment of the environmental impact and economical parameters of different types of dates anti-pest treatment should be done. The complex methodology having 7 calculation modules (engineering, environmental, climate, economical, socioeconomical, financial and human) is preferable to compare processes of bio-resource treatment [45]. The studied low temperature anti-pest treatment and storage parameters allow to calculate most of the seven mentioned modules and apparently at least engineering, environmental, climate and economical ones will be advantageous compared to other existing treatment techniques.

The results obtained in this study show that the use of negative low temperatures of $-10{ }^{\circ} \mathrm{C}$ for $4 \mathrm{~h}$ and of $-18^{\circ} \mathrm{C}$ for $2 \mathrm{~h}$ leads to elimination of the Apomyelois ceratoniae larvae and temperature of $-18{ }^{\circ} \mathrm{C}$ for $24 \mathrm{~h}$ eliminates the larvae and eggs. This method can be used as an alternative to chemical and hot treatments which influence environment, climate and date quality. The storage of dates at $-18^{\circ} \mathrm{C}$ for $360 \mathrm{~d}$ does not influence their quality and does not cause any cold damage, while storing at $+4{ }^{\circ} \mathrm{C}$ for a period above $180 \mathrm{~d}$ reduces sensorial and organoleptic characteristics. From an engineering point of view, the low-temperature treatment can be performed on existing refrigerated warehouses, so it is easy to implement. Smaller losses from pests and higher qualitative characteristics of dates should have a positive impact on the economic aspects of their production using low temperatures. Thus, treatment and storage at negative temperatures down to $-18{ }^{\circ} \mathrm{C}$ is promising for dates pests control and preserving fruit quality.

\section{ACKNOWLEDGEMENT}

This work was partially financially supported by Government of Russian Federation, Grant 074-U01.

\section{REFERENCES}

[1] Muizniece I., Timma L., Blumberga A., Blumberga D. The methodology for assessment of bioeconomy efficiency. Energy Procedia 2016:95:482-486. doi:10.1016/j.egypro.2016.09.072

[2] Kubule A., Komisarova T., Blumberga D. Optimization Methodology for Complete Use of Bio-resources. Energy Procedia 2017:113:28-34. doi:10.1016/j.egypro.2017.04.009

[3] Kittipongvises S., Chavalparit O., Sutthirat C. Greenhouse Gases and Energy Intensity of Granite Rock Mining Operations in Thailand: A Case of Industrial Rock-Construction. Environmental and Climate Technologies 2016:18(1):64-75. doi:10.1515/rtuect-2016-0014

[4] Kiprushkina E. I., Baranenko D. A., Kolodyaznaya V. S. A Comparative Study of Fuel Use and Income Analysis of Potato Production with Bacteria-antagonists in Leningrad Region of Russia. Energy Procedia 2017:113:194-200. doi:10.1016/i.egypro.2017.04.054 
[5] Kiprushkina E. I., Baranenko D. A. Increasing of food and bioenergy potato resources by microbial influence on tubers phytohormonal status. Environmental and Climate Technologies 2014:14(1):36-40. doi:10.1515/rtuect-2014-0012

[6] Vincevica-Gaile Z., Klavins M. Concentration of Elements in Food: How Can It Reflect Impact of Environmental and Other Influencing Factors? Environmental and Climate Technologies 2013:12(1):15-19. doi:10.2478/rtuect-2013-0011

[7] Food and Agriculture Organization. Crop production and trade data. [Online]. Available: www.fao.org/faostat/en/\#data/QC [Accessed 01.08.2017]

[8] Ahmed I. A., Ahmed A. W. K., Robinson R. K. Chemical composition of date varieties as influenced by the stage of ripening. Food Chem 1995:54:305-309. doi:10.1016/0308-8146(95)00051-J

[9] Elleuch M., Besbes S., Roiseux O., Blecker C., Deroanne C., Drira N., Attia H. Date flesh: Chemical composition and characteristics of the dietary fiber. Food Chem 2008:111(3):676-682. doi:10.1016/j.foodchem.2008.04.036

[10] Boudries H., Kefalasa P., Hornero-Mendez D. Carotenoid composition of Algerian date varieties (Phoenix dactylifera) at different edible maturation stages. Food Chem 2007:101(4):1372-1377. doi:10.1016/j.foodchem.2006.03.043

[11] Al-Turki S., Shahba M. A., Stushnoff C. Diversity of antioxidant properties and phenolic content of date palm (Phoenix dactylifera L.) fruit as affected by cultivar and location. J Food Agric Env 2010:8:253-260.

[12] Borochov-Neori H., Judeinstein S., Greenberg A., Volkova N., Rosenblat M., Aviram M. Antioxidant and Antiatherogenic Properties of Phenolic Acid and Flavonol Fractions of Fruits of 'Amari' and 'Hallawi' Date (Phoenix dactylifera L.) Varieties. J Agric Food Chem 2015:63(12):3189-3195. doi:10.1021/jf506094r

[13] Kulkarni S. G., Vijayanand P., Aksha M., Reena P., Ramana K. V. R. Effect of dehydration on the quality and storage stability of immature dates (Pheonix dactylifera). Food Sci Technol 2008:41:278-283. doi:10.1016/j.1wt.2007.02.023

[14] Al-Farsi M., Alasalvar C., Morris A., Baron M., Shahidi F. Compositional and sensory characteristics of three native sun-dried date (Phoenix dactylifera L.) varieties grown in Oman. J Agric Food Chem 2005:53:7586-7591. doi:10.1021/jf050578y

[15] Mansouri A., Embarek G., Kokkalou E., Kefalas P. Phenolic profile and antioxidant activity of the Algerian ripe date palm fruit (Phoenix dactylifera L.). Food Chem 2005:89:411-420. doi:10.1016/j.foodchem.2004.02.051

[16] Scott H. G. Nutrition changes caused by pests in food. In: Ecology and Management of Food-Industry Pests. FDA Technical Bulletin 4. Arlington, VA: Association of Official Analytical Chemists, 1991:463-467.

[17] Dhouibi M. H. Gestion phytosanitaire intégrée des principaux Bio-agresseurs du palmier dattier, et particulièrement, les pyrales des dates. Tunis: Climat Pub, 2013. [In French].

[18] Sousa A., Faroni L., Guedes R., Totola M., Urruchi W. Ozone as a management alternative against phosphine-resistant insect pests of stored products. $J$ Stored Prod Res 2008:44:379-385. doi:10.1016/j.jspr.2008.06.003

[19] Yahia E. M., Kader A. A. Date (Phoenix dactylifera L.). In: Postharvest Biology and Technology of Tropical and Subtropical Fruits. Cambridge: Woodhead Publishing Ltd., 2011.

[20] Ahmed M. S. H. Irradiation disinfestation and packaging of dates. In: Insect Disinfestation of Food and Agricultural Products by Irradiation. Vienna: IAEA, 1991.

[21] Bell C. H. Fumigation in the 21st century. Crop Protection 2000:19:563-569. doi:10.1016/S0261-2194(00)00073-9

[22] Aleid S. M., Dolan K., Siddiq M., Jeong S., Marks B. Effect of low-energy X-ray irradiation on physical, chemical, textural and sensory properties of Dates. Int J Food Sci Technol 2013:48(7):1453-1459. doi:10.1111/ijfs.12112

[23] Abo-El-Saad M. M., Elshafie H. A., Al Ajlan A. M., Bou-Khowh I. A. Non-chemical alternatives to methyl bromide against Ephestia cautella (Lepidoptera: Pyralidae): microwave and ozone. Agric. Biol. J. of North America 2011:2(8):1222-1231. doi:10.5251/abjna.2011.2.8.1222.1231

[24] Wakil W., Faleiro J. R., Miller T. A. (Eds.). Sustainable Pest Management in Date Palm: Current Status and Emerging Challenges. Springer, 2015.

[25] Navarro S. Postharvest treatment of dates. Stewart Postharvest Rev 2006:2:1-9. doi:10.2212/spr.2006.2.1

[26] Guizani N., Al-Saidi G. S., Rahman M. S., Bornaz S., Al-Alawi A. A. State diagram of dates: glass transition, freezing curve and maximal-freeze-concentration condition. J. Food Eng. 2010:99(1):92-97. doi:10.1016/j.jfoodeng.2010.02.003

[27] Heydari M., Izadi H. Effects of seasonal acclimation on cold tolerance and biochemical status of the carob moth, Ectomyelois ceratoniae Zeller, last instar larvae. Bulletin of entomological research 2014:104(5):592-600. doi:10.1017/S0007485314000364

[28] Yahia E. M. (Ed.). Modified and controlled atmospheres for storage, transportation, and packaging of horticultural commodities. Boca Raton, FL: CRC Taylor \& Francis, 2009.

[29] Yahia E. M. The Commercial Storage of Fruits Vegetables and Florist and Nursery Stocks. Beltsville, Maryland: USDA, 2004.

[30] Hussein F., Souial G. F., Khalifa A. S., Gaefar S. I., Mousa I. A. Nutritional value of some Egyptian soft date cultivars (protein and amino acids). Proc. 2nd symp: Date palm. King Faisal. Univ, 1989.

[31] Ben-Lalli A., Bohuon P., Collignan A., Meot J. M. Modeling heat transfer for disinfestation and control of insects (larvae and eggs) in date fruits. J Food Eng 2013:116(2):505-514. doi:10.1016/j.jfoodeng.2012.11.031 
[32] Serrano M., Pretel M. T., Botella M. A., Amoros A. Physicochemical changes during date ripening related to ethylene production. Food Sci Technol Int 2001:7:31-36. doi:10.1106/Y6MD-JJDH-LT0P-Y9AE

[33] Kader A. A., Hussein A. M. Harvesting and postharvest handling of dates. Aleppo: ICARDA, 2009.

[34] Akhatou I., Angeles F. R. Influence of cultivar and culture system on nutritional and organoleptic quality of strawberry. J. Sci. Food Agric. 2013:94(5):866-875. doi:10.1002/jsfa.6313

[35] Ismail B., Haffar I., Baalbaki R., Henry J. Physico-chemical characteristics and sensory quality of two date varieties under commercial and industrial storage conditions. LWT-Food Sci. Technol. 2008:41(5):896-904. doi:10.1016/j.1wt.2007.06.009

[36] Salari R., Karazhiyan H., Mortazavi S. A. Study the effect of different packaging films on physiochemical properties of different Iranian dates during storage. Am-Eurasian J Agric Env Sci 2008:3:485-91.

[37] Benchabane A., Abbeddou S., Bellal M. M., Thibault J. F. Evolution of pectins and polygalacturonase activities during maturation of date Deglet-nour. Sciences des Aliments 2006:26:233-246. [In French]

[38] AbdElgawad H., Farfan-Vignolo E. R., de Vos D., Asard H. Elevated CO2 mitigates drought and temperature-induced oxidative stress differently in grasses and legumes. Plant. Sci. 2015:231:1-10. doi:10.1016/j.plantsci.2014.11.001

[39] Chen F. X., Liu X. H., Chen L. S. Development changes in pulp organic acid concentration and activies of acid-metabolizing enzymes during the fruit development of two loquat (Eriobotrya japonica Lindl.) cultuvars differing in fruit acidity. Food Chem. 2009:114:657-664. doi:10.1016/j.foodchem.2008.10.003

[40] Zhang D., Lee D. J., Tippetts B. J., Lillywhite K. D. Date maturity and quality evaluation using color distribution analysis and back projection. J Food Eng 2014:131:161-169. doi:10.1016/j.jfoodeng.2014.02.002

[41] Barreveld W. H. Date Palm Products. Rome: FAO Agricultural Services Bulletin, 1993.

[42] Achour M., Bagga N. Effect of storage conditions on the color degradation of Tunisian Deglet Nour dates. Fruits 2005:60(1):41-46.

[43] Hazbavi I., Khoshtaghaza M. H., Mostaan A., Banakar A. Effect of postharvest hot-water and heat treatment on quality of date palm (cv. Stamaran). J Saudi Soc Agric Sci 2015:14(2):153-159. doi:10.1016/j.jssas.2013.10.003

[44] Weichmann J. The effect of controlled-atmosphere storage on the sensory and nutritional quality of fruits and vegetables. Hort Rev 1986:8:101-126. doi:10.1002/9781118060810.ch3

[45] Blumberga D., Muizniece I., Blumberga A., Baranenko D. Biotechonomy framework for bioenergy use. Energy Procedia 2016:95:76-80. doi:10.1016/j.egypro.2016.09.025
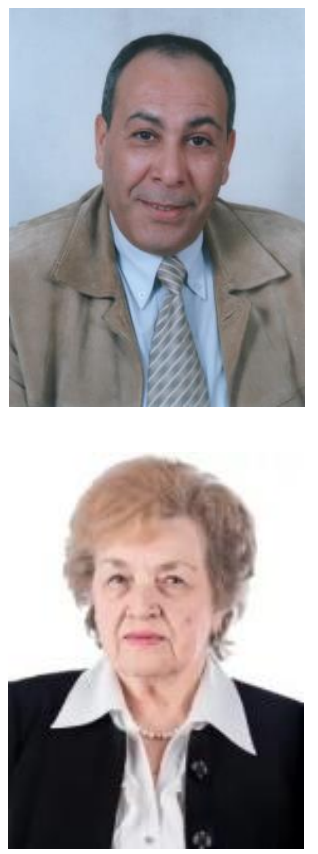

Ahmed Lallouche graduated from the Odessa Technological Institute of the Refrigeration Industry in 1982 as an engineer in "Refrigeration and Compressor Machines and Facilities". He received the Ph.D. degree from ITMO University in 2012.

From 1982 to $1986 \mathrm{Mr}$. Lallouche worked as an engineer and then a head of the department in the state firm "Sonacat", Annaba, Algeria. From 1986 he held different positions from a head of the department to a director of refrigerating warehouse and regional director in National Company of Refrigeration, Skikda Algeria. From 2003 to date he also became a legal expert on refrigeration, air conditioning and industrial risks.

Research interests: refrigerated storage of food products, Algerian domestic foods, resource saving technologies.

Valentina Kolodyaznaya graduated with honors from the Leningrad Technological Institute of the Refrigeration Industry. She received the Ph.D. degree and later $\mathrm{PhD}$. Habil. degree from the same institute for her works in "Storage and Refrigeration Technology of Food Products".

Since 1975, she worked in the Institute's problem laboratory as a senior researcher, and from 1982 to 1990, - the head of this laboratory. From 1990 to date she works as a professor and has supervised more than $20 \mathrm{Ph} . \mathrm{D}$. and PhD. Habil. theses.

Research interests: theoretical and experimental research in the field of refrigeration technology and processing of agricultural raw materials of animal and vegetable origin. 

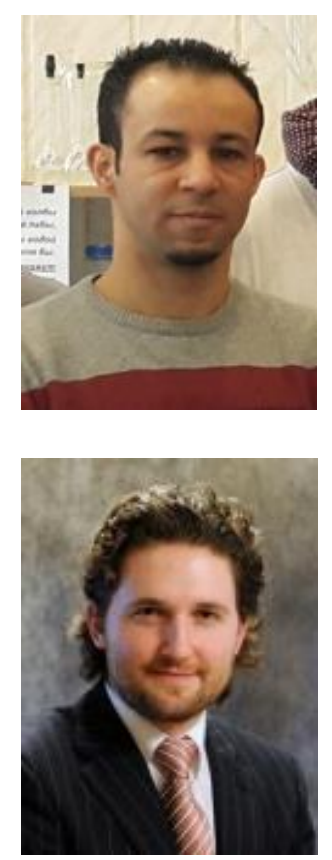

Mohamed Said Boulkrane graduated bachelor's degree from Constantine University in 2007 and Master's degree from Saint-Petersburg State Technological Institute in 2012. He received the $\mathrm{Ph} . \mathrm{D}$. degree from ITMO University in 2015.

Since 2016 Dr. Boulkrane works at ITMO University's International research centre "Biotechnologies of the Third Millennium" as a postdoctoral researcher.

Research interests: postharvest biotechnology, food storage and saving, microbiology, food biotechnology.

Denis Baranenko graduated with honors from the Saint-Petersburg State University of Refrigeration and Food Engineering (later - Institute of Refrigeration and Biotechnologies, ITMO University) in 2003. He received the Ph.D. degree from the same university in 2006. Since 2006 works there as an associate professor, from 2011 directed the work of a research laboratory, from 2014 heads the International research centre "Biotechnologies of the Third Millennium".

Research interests: resource and energy saving food biotechnologies, biologically active compounds, functional food products. 